\title{
A literary figure or patriarchal reality? Reflections on the 'éšet hayil in light of depictions of womanhood from selected Yorùbá and Sotho proverbs
}

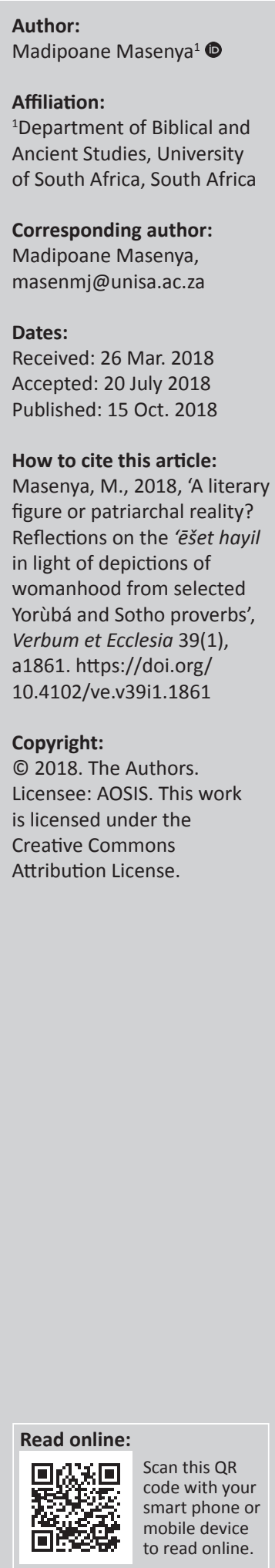

In varying Jewish and African contexts (cf. the Yorùbá and Sotho in the present essay), the 'éšet hayil is regarded as a historical figure who should serve as a model for women both young and old. As an organic scholar within an African context, I am both fascinated and also challenged by how biblical notions of gender and womanhood, as portrayed in the paean on the 'esšet hayil in Proverbs 31:10-31, seem to be at variance with notions of gender and womanhood as depicted in some Yorùbá and Sotho proverbs. Noting the emphasis in Proverbs 31:10-31 on the positive image of the 'êšet hayil as the ideal wife, this article shows that overall, in the African proverbs, the woman is depicted positively as a mother, though many proverbs (cf. especially the Yorùbá proverbs) cast the woman as a wife in a negative light. It is argued that the epitome of womanhood, which in Proverbs 31:10-31 is the ideal wife, appears to stand in tension with the image of a good mother and of a bad wife observed in some of the African proverbs. This article therefore focuses on the kind of gender- and family-conscious hermeneutic that may be envisioned when Proverbs 31:10-31 is read in the Yorùbá and Sotho contexts.

Intradisciplinary and/or interdisciplinary implications: The research carried out in this article entails Old Testament Studies, Gender Studies and African Languages. Sotho and Yorùbá proverbs on womanhood are used as a hermeneutical lens to interrogate the text of Proverbs 31:10-31, resulting in fresh insights on womanhood. The resultant output makes a needed contribution in challenging patriarchal ideologies and contexts.

\begin{abstract}
Who can find a virtuous wife,
For her worth is far more precious than rubies ( $\operatorname{Pr} 31: 10$, MEV)

To die without getting married and without children is to be completely cut off from the human community ... to become an outcast and to lose all links with mankind [sic]. Everybody therefore must get married and bear children: that is the greatest hope of the individual for himself [sic] and of the community for the individual (Mbiti 1989:131).
\end{abstract}

\section{Introduction}

At face value, the paean in praise of the 'e-šet hayil in Proverbs 31:10-31 may appear to give some pointers to an ideal family set-up in the context of its production (cf. Yehud). However, the theme of family relationships cannot be restricted to the post-exilic era because the concept of 'family' is as old as Israel herself. Claudia Camp (1985:187) could thus argue that present-day readers of the book of Proverbs are not compelled to date the Proverbs poems of 1-9 and 31 in the post-exilic era because there is a possibility that older works were used anew in the latter context. ${ }^{1}$ Even more importantly for the present investigation, within the various contexts of the reception of this poem, including the Yorùbá and Sotho African contexts, the female figure presented by the poem is usually regarded as a historical figure who should serve for many an African woman as a model to be emulated. Even in present-day Jewish contexts, argues Fox (2009), ' ... when recited to a wife and mother [as in contemporary Jewish practice], it [the enconium] expresses gratitude for her achievements and contributions to the family' (p. 905; texts in brackets are the author's).

What seems to be at the core of the paean on the 'éšet hayil are notions of what it means or what it must mean to qualify as a married woman of substance. The text's focus is not on any woman. It is on a woman who has been found by a man, that is, a heterosexually married woman.

1.For the purposes of the present article, it will suffice to date the redaction or compilation of Proverbs 31:10-31 in line with the genera dating of the whole book in the post-exilic period. This does not necessarily entail that the material contained in this poem is exclusively post-exilic. In view of the older nature of family wisdom, on which the poem and some parts of the book focus, the possibility cannot be ruled out that we are dealing with pre-exilic material in this paean (cf. Camp 1985:187; Lyons 1987:237). 
The paean appears to prescribe the qualities of worthy womanhood from the viewpoint of its (male) composer(s): 'Proverbs 31:10-31 contains the poem on the capable wife that praises her from a male perspective' (Sakenveld 2009a:872). What typifies a virtuous woman, this 'good [thing]', which in the view of the poet is difficult to find? However, whatever it is that the poem seeks to convey about worthy womanhood appears, to an extent, to be at variance with what worthy womanhood is, or should entail, as evidenced from selected Yorùbá and Sotho proverbs.

While it is acknowledged that there are differences between the Israelite and African sapiential traditions with regard to time, culture, language and geographical location, to name but four, research has also recognised some points of resemblance between the worldview embedded in some of the proverbs in the book of Proverbs (including the worldview that embeds the paean being investigated here) and the one underlying many African proverbs (Burden \& Bosman 1982:84; Kimilike 2006; Masenya 1989). The resemblances between the proverbs of the preceding cultures could be accounted for based on the assumption that both the Israelite and African peoples share a common optimistic outlook on reality.

The main question that is being addressed in this article is as follows: Given the apparent tensions between the images of womanhood as they are portrayed in selected Yorùbá and Sotho proverbs and such images as they appear in the book of Proverbs, epitomised in the ode in praise of the 'éšet hayil, and also given the kind of impact that the Christian scriptures continue to wield in varying African contexts, what kind of hermeneutic may emerge if the proverbs from these different contexts are brought together? Would the ensuing genderand family-conscious hermeneutic assist interested African women to navigate the perceived tensions within these traditions with success?

In the following paragraphs, a brief overview of selected proverbs from the Yorùbá and Sotho contexts is presented. The African proverbial material will then serve as a hermeneutical lens to engage the figure of the 'éšet hayil as she is featured in Proverbs 31:10-31.

\section{Glimpsing ideal womanhood in African contexts}

Òrișà bí ìyá kò sí. İyá là bá má a bọ. (Yorùbá proverb)

İyá ni wúrà, baba ni díngí.

Mmago ngwana o swara thipa ka bogaleng. (Sotho proverb)
[There is no deity like mother. A mother is worthy of being worshipped.]

[Mother is gold. Father is a mirror.]

[A child's mother holds the knife by its cutting edge.]

\section{Women as mothers in selected Sotho proverbs}

Go tswala ke go feka maano (Rakoma 1971).
[To give birth is to devise plans.]
The tenor of this proverb reveals that it is worthwhile to have one's own children as it is simply assumed that they will take care of one's needs during old age.

A ba tswalwe ba ate gobane mo-na-le-pelo ga a tsebjwe

[Let them be birthed and let (Rakoma 1971). them increase for the one with a long heart is not known.]

Its tenor is: women should bear as many children as possible as some of these may grow up to be good adults who would be able to take care of the needs of their parents among others.

Mmago ngwana o swara thipa ka bogaleng.

[A mother holds the knife by its cutting edge.]

The proverb reveals that a mother will go out of her way, even taking risks at times, for the safety and welfare of her children.

Although the role of a woman as a good mother is celebrated in the preceding proverbs, other proverbs recognise the existence of bad mothers, as in the following examples:

\section{Images of a bad mother in some Sotho proverbs}

Lefotwana ge e se la gago, o
hloba le gaela.
Motho ge e se mmago, le ka
metse a ka go tšhela
(Rakoma 1971).

[If a birdling does not belong to you, you remove its feathers even if it cries bitterly.]

(Rakoma 1971).

[If a human being is not your own mother she or he can even run (hot) water over you.]

Some Yorùbá proverbs also celebrate women as mothers. To this we now turn.

\section{Women as mothers in Yorùbá proverbs}

Yorùbá culture, just like the Akan culture, places the welfare of children and the home above everything else (cf. Labeodan 2015). According to Akintunde (2006), the preceding attribute was exhibited in the past as well as within contemporary African society. Nothing else takes precedence (p. 158). Hence, there is the proverb, 'when one mother or child lies dying, one does not pursue disputes' (Oduyoye 1995:60).

The portrayal of women as good and as bad mothers appears to be more glaring in the Yorùbá proverbs than in the Northern Sotho proverbs.

\section{Images of a good mother}

$\begin{array}{ll}\text { Oriṣa bí ìá kò sí. İyá là bá má } & \text { [There is no deity like mother. } \\ \text { A bọ. } & \text { A mother is worthy of being } \\ & \text { worshipped.] } \\ \text { İyá ni wúrà, baba ni dingí. } & \text { [Mother is gold. Father is a } \\ & \text { mirror.] }\end{array}$

Hence the expression, 'No orisa is as sacred as the mother'. (All fetishes and all witchcraft are inferior to the womanmother; she is the strongest; cf. Schipper 1991:85, as quoted by Olojede 2012:197). 
Àgbàká labiyamo ńgbàjá mọ́ omọo rẹ.

[It is completely and securely that a mother with a baby strapped to her back supports the child with a strip of cloth.]

The proverb's tenor reveals that one must be thorough in discharging one's responsibilities.

Abiyamo kì ì rìn kó șánwọ ahá.

[A nursing mother does not venture away from home without a cup.]

Its tenor reveals that a mother must be prepared to nurse her baby.

As already noted, some Yorùbá proverbs feature portraits of a bad mother, as in the following examples.

\section{Images of a bad mother}

Obìnrin bímọ fún ni kò pé kó má pa ni; obìnrin kò bímọ fún ni kò pé kó má pa ni.

[That a woman has had one's child does not mean she cannot kill one; that a woman has not had one's child does not mean she may not kill one.]

Broadly applied, the proverb displays suspicion about women as it reveals that intimacy cannot protect one (man) against a woman.

In both the Sotho and Yorùbá cultures, a woman is also celebrated as a wife, ${ }^{2}$ as will become evident from the following proverbs.

\section{Woman as wife in Sotho proverbs}

\section{Images of a good wife}

Mosadi ke tšhwene, o lewa mabogo (Rakoma, 1971).

[A woman is a baboon, her hands are eaten.]

The beauty and delight that a woman can cause are revealed by her diligence in fulfilling her (domestic) duties and also taking care of her husband (Masenya [ngwan'a Mphahlele] 2004:133).
Monna ke peu, ga a swarwe manenolo.
[A woman should honour her husband.] (Ziervogel \& Mokgokong 1975:856).
Tšhilo le lwala re tšere, le tlo šala
[The diligent girl is now le eja lewana. married.]
Once a girl (kgadi) gets married, her family finds it difficult to cope with household chores, while her in-laws (ba bogadi) become proud and grateful that their domestic chores will be attended to. The expectation of female hard work (also within the context of marriage; cf. proverb 1 above) is revealed in this proverb.

The tenor of the preceding proverbs attach the worthiness of a woman to her marital status, especially a woman's ability to take care of her household's needs, in particular,

2.The language of marriage proverbs indicates that a wife only reflects the stage of the marriage and a man's competence as a husband ... Society demands that she stays married, because a woman has no dignity outside marriage. (Oduyoye 1995:68; italics are the author's). those of her husband. Her husband's authority over her is unquestionable.

Just like in the role of motherhood, not all wives could be celebrated as good wives, as will become clear from the following proverbs:

\section{Images of a bad wife}

Botse re llela boswana, bošwanyana bo a lahletša.

$$
\begin{aligned}
& \text { Se bone thola boreledi, teng ga } \\
& \text { yona go a baba. }
\end{aligned}
$$

Tšhwenegatšana o matepe o gana ge o bitšwa ke boroto.
[Beauty we cry for the darker (-skinned) one(s), the lighter (-skinned) lead(s) astray.] Outward (female) appearances can be deceptive.

[Do not be deceived by the smoothness of a thola (a beautiful smooth yellow fruit), it is bitter inside.] External (female) appearances can be deceptive.

[Female baboon, you are spoiled as you refuse the summons from a male baboon.]
We now turn to the Yorùbá proverbs on the image of a woman as a wife.

\section{Images of a good wife in Yorùbá proverbs}

In charge of cooking and kitchen affairs:
Áwàrí lobinrin ńwá nńkan ọbẹ.

$$
\begin{aligned}
& \text { [Seeking-until-finding is how } \\
& \text { a woman seeks ingredients } \\
& \text { for a stew.] }
\end{aligned}
$$

The dutiful person (wife) does not permit difficulties to keep her from accomplishing her duty.

Obẹ tí baálé kì je, ìyáálé ilé kì sèé.

À ńsọ̀ọ̣ elégédé, obìnrín mibèrè ohun tía ñ nọo, a ní ọrọ okùnrin ni; bí a bá kó elégédé jọ, ta ni yó sè é?

Bí obìnrin ò báj jowú, obe rẹ kì dùn.

[The soup that the husband does not eat, the wife does not cook.]

[We are discussing pumpkins; a woman asks what we are discussing, and we respond that it is men's talk; after we have gathered the pumpkins, who will cook them?]

[If a woman is not jealous, her soup cannot be tasty.]
The preceding proverb is another marriage- and polygamythemed proverb that notes a potential merit in polygamy because of its inherent competitive nature.

Obẹ tí baálé kì í jẹ, ìyálé ilé kì i IThe sort of stew that the man sèé. of the house will not eat, the woman of the house should not cook.]

One should not do what one knows one's comrades hate. 


\section{Images of a bad wife}

\section{Being inherently wicked or evildoers or witches}

Kàkà kí ó sànl'ára ìyá àjẹ, ó figbogbo omo bí obinrin; eye

[Instead of mother-witch's condition to improve, all the children she bears turn out to be female; birds beget more birds (a reference to witches 'flying' at night).]

Despite all efforts the fortunes of a person continue to be bad. Obìnrin bímo fún ni kò pé kó má pa ni; obìnrin kò bímo fún ni kò pé kó má pa ni.

[That a woman has had one's child does not mean she cannot kill one; that a woman has not had one's child does not mean she may not kill one.]

Intimacy is no protection against a woman.

Okùnrin tí kò kú, obìnrin rẹ ni kò tî̀ páá.

[If a man is not yet dead, it is because his woman is yet to kill him.]

Ito e pe l'ẹn ó di wárápá, egbo pe l'ẹe ó di jakute; bi obìnin báá pe n'ile okọ àjẹ nii dà.

[When saliva stays long in the mouth, it becomes epilepsy; when a sore stays long on the leg, it becomes putrid. If a woman stays long in her husband's house, she becomes a witch.]

\section{Bad wives and the penalties}

\section{Abused (bad) women?}

İyàwó șe ơràn kan tán; okọ è-é șe òràn-an nkò-jẹ-mó.

[The wife has done the unpardonable; her husband has adopted an I-will-not-eatany-longer attitude.]

The preceding proverb is said in the context of people who have caused unpardonable offence.

İpàsán tí a fi na ìyálé móbe láàjà fún ìyàwó.

[The whip used on the senior wife is resting on the rafters waiting for the new wife.]

One should not assume that the misfortune that befell those who went before one would pass one over.

It is worth noting that unlike in the Sotho collection, quite a few proverbs abound on women as bad wives within the Yorùbá proverbial collection.

Having glimpsed the depictions of womanhood from the preceding Sotho and Yorùbá proverbs, we now turn to the poem in praise of the 'ěšet hayil as reflected in Proverbs 31:10-31.

\section{The 'éšet hayil in light of depictions of womanhood from some Yorùbá and Sotho proverbs}

As already noted, the focus of this investigation is on the kind of gender- and family-conscious hermeneutic that may be envisioned when Proverbs 31:10-31 is read in the Yorùbá and Sotho contexts.
In the Sotho proverbs (cf. also the Yorùbá proverbs), womanhood is first and foremost linked to heterosexual marriage. Like in the Hebrew Bible, the words for 'woman' and 'wife' are captured by the same word (cf. mosadi). A mosadi (read: a wife, a married woman) is celebrated as a communal wife (cf. also in the Yorùbá context, Olojede 2012:198). The 'ěšet hayil basically belongs in her husband's household, though the household is referred to as hers. An African woman is a wife and a nurturer of her husband (cf. the expression mmago nna (literally, 'the mother of myself'), fondly said by a husband to his wife. In both African contexts, a married woman (wife) is also celebrated for using her reproductive capacities effectively. A woman is thus celebrated as a mother. Although the sex of a specific baby is not mentioned in the (listed) proverbs, the birth of sons causes more joy in our patriarchal, patrilineal African contexts. The birth of girls may also be celebrated to some extent given the important role that they will later play, especially as paternal sisters and the proceeds that would accrue from the bride price.

The received interpretations of biblical texts, including the text of Proverbs 31:10-31 (both in churches and academia) are not always helpful. On the one hand, academia to a greater extent tends to detach biblical texts from the harsh sociopolitical and socio-economic realities on the ground. On the other hand, churches interpret the paean mostly in a literalist, taxing way, for example, the ēšet hayil is hardly, if at all, presented as a literary figure. The 'éšet hayil is regarded as a historical figure from whom African women who sit in the pews should take their cue. Although present-day gender-conscious scholars may take issue with such literalist readings of female texts in the Christian scriptures, the readings may not be totally devoid of significance as they may bring the following helpful elements about the 'éšet hayil to light.

As an attainable ideal?

- The 'éšet hayil manages the affairs of her household (including ensuring the welfare of all household members - husband, children and servants) with efficiency.

- She is assertive, independent and has a sense of self-love.

- The 'éšet hayil is committed to her relationship with her husband and thus seems to delight in enhancing his prestige and his name.

- She is a perfect model of industry.

- She has a sense of justice as her hands are extended to the poor and needy.

- She dispenses words of wisdom from her mouth.

- Her life centres on the fear of the Lord.

- She is a businesswoman.

The 'êšet hayil is also an unattainable ideal. Could she fit in smoothly with the category of a mere literary figure?

- She is presented as an overworked human being. In everyday life, stress cannot be sustainable as it could also be fatal.

- She is an elite woman. The kind of resources that the 'éšet hayil possesses are far beyond the reach of many African 
women, many of whom may not even be on the level of her skilled servants.

- Her nuclear (monogamous) family is at variance with those African families that are polygynous.

- Connected to the preceding observation, other types of families and partnerships will feel excluded from the ideal provided by Proverbs 31:10-31: single-parented families; children-parented families and families constituted by the members of the LGBTQI community, among others.

\section{The 'ēšet hayil via African proverbs: A gender- and family-conscious biblical hermeneutic?}

Selected Sotho and Yorùbá proverbs will be used to re-read the 'éset hayil in light of the definitions gleaned from African texts.

\section{Woman as mother}

Mmago ngwana o swara thipa ka bogaleng. (Northern Sotho)

[A mother holds the knife by its cutting edge.]

A mother will go out of her way, even taking risks at times, for the safety and welfare of her children.

Áwàrí lobinrin ńwá nńkan ọẹ. (Yorùbá)

[Seeking-until-finding is how a woman seeks ingredients for stew.]

The dutiful person does not permit difficulties to keep her from accomplishing her duty.

The preceding African proverbs reveal the duties of a woman as one who holds the family together by ascertaining with all her loyalty and commitment that the family functions smoothly and efficiently. Women are the ones who work harder to ensure that the household's welfare is catered for, especially as it pertains to the needs of children. A woman as a mother of all in the household is expected to make sure that the activities of the house run smoothly (cf. the Northern Sotho proverb). Like the 'ěšet hayil, an African woman can be the actual doer of household chores. She could also enlist the assistance of older children, other wives or a domestic help, depending on her socio-economic status. Her commitment to the smooth running of the household would not be deterred by the difficulties she may encounter along the way (cf. the Yorùbá proverb). Some of the proverbs, though, especially the Yorùbá ones, seem to foreground the care that should first and foremost go to her husband, perhaps even more than to her children.

Commentators have noted the efficient management of a complex household as one of the distinguishing qualities of the 'éšet hayil. The 'ěšet hayil's experience through the years has enabled her to master the skill of managing a household and thus qualified her to be among the wise women, for as Sakenveld (2009a) argued:

[f]irst, wisdom was practical rather than theoretical - knowing how to do something. A king was wise because he knew how to govern well $\ldots$ and a woman was wise because she knew how to manage a household. (p. 657)

African wives and mothers who displayed these skills would be identified as the ones who understood the teachings they had received from the initiation schools and what the elderly women would have taught them about womanhood when they got married.

The ode to the 'éšet hayil stresses what she does for the household and its members, that is, her husband (vv. 11-12; 28-29), her maidservants (v. 15), the poor and the needy (v. 20), herself (v. 22) and her sons and her husband (vv. 28-29). In the latter verses, she is not depicted as doing something for them, but they 'do' something to her, not by their hands, but by their mouths.

\section{An industrious woman}

Unlike many an African woman, as part of the management of her complex household, the 'éšet hayil, an elite woman as previously noted, straddles the space between the private sphere of the home, which is depicted as hers, and the public sphere, not of political life but of business life. Although the Woman of Worth is not pictured as inhabiting the city gates, thus taking an active part in the political affairs of that male sphere, her influence is felt at the gates, where her husband receives the honour on account of her industry. She thus displays the qualities of worthy womanhood.

African women in both the Sotho and Yorùbá proverbs and the 'éšet hayil are portrayed as industrious.
Mosadi ke tšhwene, o lewa
[A woman is a baboon, her mabogo. (Sotho proverb) hands are eaten.]

The beauty and delight that a woman can cause are revealed by her diligence in fulfilling her (domestic) duties and also taking care of her husband (Masenya [ngwan'a Mphahlele] 2004:133).

\section{Tšhilo le lwala re tšere, le tlo šala [The diligent girl is now le eja lewana. (Sotho) married.]}

Once a girl (kgadi) is married, her family finds it difficult to cope with household chores, while her in-laws (ba bogadi) become proud and grateful that their domestic chores will be attended to. The mentality of female hard work (also within the context of marriage; cf. proverb 1 above) is also revealed in this proverb.

$\begin{array}{ll}\text { Mma o tlile tlala o a }(n) y a . & \text { [Mother has come, hunger } \\ \text { (Sotho) } & \text { will be in real trouble.] }\end{array}$

Obẹ tí baálé kî́ je, ìyáálé ilé kì _ [The soup that the husband sèé. (Yorùbá) does not eat, the wife does not cook.]

$\begin{array}{ll}\text { Obè tí baálé kì íjẹ, ìálé ilé kì i } & \text { [The sort of stew the man of } \\ \text { sèé. } & \text { the house will not eat, the } \\ & \text { woman of the house should } \\ & \text { not cook.] }\end{array}$

One should not do what one knows one's comrades hate.

The first Sotho proverb, mosadi ke tšhwene, o lewa mabogo [a woman is a baboon, her hands are eaten (passive)] likens a hardworking woman to a baboon, possibly because a baboon is classified in this culture as industrious animals. It is important to note that the efficient management of a household cannot be separated from the use of a woman's hands. Also, although the hands of a married woman are to be eaten by all in the household, a husband, according to the 
proverb's tenor, has to receive a bigger share of the consumption, including the satisfaction of his sexual desires as well. Interestingly, a (male) counterpart of the proverb reveals precisely the preceding function, though not necessarily performed within his household! Monna ke tšhwene, o ja ka matsogo a mabedi. [A man is a baboon, he eats (active) with two hands.] The tenor of this proverb is that even if he has a wife, a married man may have sexual encounters with other women extra-maritally. The proverb about a diligent girl being married also points to the excitement of the recipient (husband's) family, as the new additional hands would mark the arrival of plenty. The children in the family can then sing: Mma o tlile, tlala o a ( $n$ )ya [Mother has come, hunger you are in real trouble].

From the Yorùbá proverbs, it is also clear that the husband, more than all the other family members, is the one to enjoy the fruits of his wife's domestic labour (read: kitchen chores).

The 'éšet hayil does not eat the bread of idleness (v. 27). The better part of the poem is dotted by action, her actions: 'brings', 'rises', 'puts her hand', 'her palms extended', 'makes' and so on. Like the proverbial baboon, the 'ěšet hayil's hands are eaten by all the members of her household, that is, husband (vv. 11-12), maidservants (v. 15), herself (v. 22), her sons (and husband) (vv. 28-29), including even those who are not members of her household, that is, the poor and the needy (v. 20). From the preceding qualities, could she qualify as a good wife and a good mother as well? As per Murphy (1998):

The husband's trust in her is manifested by the relative absence of any significant mention of him in the poem, except for his lounging at the city gate, v. 23, and praising her, vv. 28-29. (p. 246)

The answer to the question on whether the 'éšet hayil is a good wife is thus positive. Why? Proverbs $31: 10-31$ is a poem in praise of a wife of substance. It thus makes sense that among the members who would naturally have formed part of the 'éšet hayil's nuclear household, that is, her husband and her children (read: sons), her husband would have been the one to be foregrounded. The paean is a man's praise to a woman of substance. It also follows that as the description of the 'éšet hayil is cast in a poem, she could not, unlike in the case of the portrait of a woman in many Yorùbá proverbs, have been portrayed negatively as a bad wife or a bad mother. The sages have already given readers portraits of her counterparts in earlier chapters (cf. Woman Folly and Woman Stranger).

As for the 'e-šet hayil's reproductive capacities (cf. her role as a mother), the poem does not specify the number of sons who rise up and call her happy. From the poem's mood though, as well the importance of the re-establishment of the new Jewish community in Yehud, it is possible that a wife of substance would have been the one who had many (male) children. The challenge would only be how she would navigate sharing her hands and palms between adults (husband and maidservants) and children of different age categories. As a mother, she takes care of the needs of her children in the household, also teaching them the Torah with wisdom (v. 26).
The quality of the 'éšet hayil as a mother who bears and nurtures many children is covert compared to its counterpart in African proverbs (cf. Sotho proverbs in particular).

\section{Conclusion}

The 'éšet hayil is portrayed as working very hard to make sure that the lives of other human beings, especially those who belong to her household, are taken care of. What is clear, though, is her solitary life in terms of her connectedness and relationships with other human beings, including her husband. She seems married to her many tasks. She would not quite fit the African ethos of botho or ubuntu [humanness or kindness], in which a human being (like herself) becomes one because of other human beings. While she basically displays botho to others, including those who desperately need it (cf. the poor and the needy), she cannot seem to receive the botho from others, or does she? Her portrait, unlike the depictions of bad and good mothers in several African proverbs, is viewed only in a good light: 'She does him good and not evil all the days of her life' (Pr 31:12).

She is a rich woman, a member of the haves, a quality disconnected to the realities of many an African woman. Yet, despite all these points of disconnect between her portrait and those reflected in selected Sotho and Yorùbá proverbs, the 'éšet hayil is supposed to be celebrated as a model to be emulated by women, especially those for whom the Christian Bible remains normative. Such women appear to be stuck between present-day images of womanhood and traditional images re-inscribed by the discourses of the African renaissance, decoloniality and fundamentalist biblical hermeneutics. The following pertinent question thus remains: In light of the preceding points of disconnect between some of the salient features of the 'éset hayil and depictions of womanhood from some African proverbs, how may (African) biblical scholars, especially organic ones, enable an accessible, woman-friendly, family-conscious biblical hermeneutic for those who are desperately in need thereof? Would the ensuing gender- and family-conscious hermeneutic assist interested African women to navigate the perceived tensions within these traditions with success? This article has hopefully enabled the reader to gain a glimpse into the kind of gender- and family-conscious hermeneutic that may be envisioned when Proverbs 31:1031 is read in the Yorùbá and Sotho contexts.

\section{Acknowledgements Competing interests}

The author declares no competing interests with regard to the writing of this article.

\section{References}

Akintunde, D.O., 2006, 'Women as healers: The Nigerian (Yoruba) example', in I.A. Phiri \& S. Nadar (eds.), African women, religion and health: Essays in honor of Mercy Amba Ewudziwa Oduyoye, pp. 157-169, Cluster Publications, Pietermaritzburg.

Burden, J.J. \& Bosman, H.L., 1982, Only guide for OTB302-3, University of South Africa, Pretoria. 
Camp, C.V., 1985, Wisdom and the feminine in the book of proverbs, JSOT Press, Sheffield. Fox, M., 2009, Proverbs 10-31: The Anchor Yale Bible, A new translation with introduction and commentary, Yale University Press, New Haven, CT.

Kimilike, L.P., 2006, 'An African perspective on poverty proverbs in the book of Proverbs: An analysis for transformational possibilities', unpublished Doctor of Theology thesis, University of South Africa, Pretoria, South Africa.

Labeodan, H.A., 2015, 'Exploring Yoruba proverbs with feminine lexis as a tool for reimagining African womanhood', in Ross, R. \& Emega-Eteko, R. (eds.), Unraveling and reweaving sacred canon in Africana womanhood, pp. 21-34, Lexington Books, Lanham, MD.

Lyons, E.L., 1987, 'A note on the book of Proverbs 31:10-31', in K.G. Hogland (ed.), The listening heart: Essays in wisdom and the Psalms in honor of Roland E. Murphy, pp. 235-237, Sheffield Academic, Sheffield.

Masenya, M.J., 1989, 'In the school of wisdom: An interpretation of Yorùbá and Sotho some Old Testament proverbs in a Northern Sotho context', unpublished M.A. dissertation, University of South Africa, Pretoria, South Africa.

Masenya (ngwana' Mphahlele), M., 2004, How worthy is the woman of worth? Rereading Proverbs 31:10-31 in African-South Africa, Peter Lang, New York.
Mbiti, J.S., 1989, African religions and philosophy, Heinemann, Oxford.

Murphy, R.E., 1998, Word biblical commentary, Vol. 22, Proverbs, Thomas Nelson, Nashville, TN.

Oduyoye, M.A., 1995, Daughters of Anowa: African women and patriarchy, Maryknoll, Orbis, NY.

Olojede, F., 2012, '(Un)Popular images of women in Yoruba popular culture: A quest for human dignity', in J. Claassens \& S. Viljoen (eds.), pp. 187-205, Sacred selves: Essays on gender, religion and popular culture, Griffel, Cape Town.

Rakoma, J.R.D., 1971, Marema-ka-dika a Sesotho sa Leboa, Van Schaik, Pretoria.

Sakenveld, K.D., 2009a, The new interpreter's dictionary of the Bible, Me-R, vol. 4, Nashville, TN.

Sakenveld, K.D., 2009b, The new interpreter's dictionary of the Bible, S-Z, vol. 5, Nashville, TN.

Schipper, M., 1991, Source of all evil: African proverbs and sayings on women, Alison and Busby, London.

Ziervogel, D. \& Mokgokong, P.C., 1975, Comprehensive Northern Sotho dictionary, Van Schaik, Pretoria. 